\title{
Molecular Characterization of the Gene Encoding SJCHGC 03921 Protein of the Lung Stage of Schistosoma Mansoni (7-Days Schistosomula)
}

\author{
Samir Mahgoub \\ Department of Biochemistry, Faculty of Medicine, Al-Minia University
}

\begin{abstract}
The parasitic helminth Schistosoma mansoni (S. mansoni) is a major public health concern in many developing countries. Over 200 million people have, and another 600 million are at risk of contracting schistosomiasis which is one of the major neglected tropical diseases. For this dangerous disease the development of long lasting immunity through vaccination may be the real solution to control the spread of the disease. The molecules on the surface or associated with the tegument of $S$. mansoni are a major focus as potential vaccine candidates. In the present study, all surface and internal proteins of the lung stage of the parasite were screened to increase the chances for the discovery of a unique protein of the parasite to be targeted by the immune system of the host. Pooled sera were collected from $\boldsymbol{S}$. mansoni chronically infected patients, then, purified over a column made of soluble extract of the lung stage (7-days schistosomula) of $\boldsymbol{S}$. mansoni. The eluted antibodies were used to immunoscreen $\lambda$ gt11 cDNA library of 7-days schistosomula. A number of cDNA clones were identified after three rounds of immunoscreening and plaques purification. The phage DNAs of the isolated clones were amplified by polymerase chain reaction (PCR) using $\lambda$ gt11 forward and reverse primers, then, cloned in $\boldsymbol{P C} \boldsymbol{R}^{T M}$ II plasmid vector. The isolated clone 4-65 was fully sequenced and was found encoding the gene of SJCHGC 03921 protein of 7-days schistosomula of S. mansoni. Also, the $0.9 \mathrm{~kb} c D N A$ clone was found to have a single open reading frame (ORF) encoding 269 amino acids, which exhibited 94\% homology with the gene of SJCHGC 03921 protein of Schistosoma japonicum.
\end{abstract}

\section{INTRODUCTION}

Despite the mass chemotherapy programs, schistosome reinfection rates and prevalence continue to be unexpectedly high. Similarly rebound prevalence and morbidity will be high; an evitable consequence if ongoing interventions are not sustained $^{l}$. Furthermore, there is increasing concern about the development of parasite resistance to chemotherapy. Consequently, vaccine strategies represent an essential component for the future control of schistosomiasis as an adjunct to chemotherapy ${ }^{2}$.

Schistosomes are truly a formidable adversary that won't easily be beaten. It has been shown that hosts can develop an acquired immunity against challenge infection either after primary infection, immunization with irradiated larvae, or with defined antigens ${ }^{3,4}$.

A vaccine would enhance attempts to control and eradicate the 
disease that currently relies on treatment with a single drug 5 .

An effective schistosome vaccine is a desirable control tool but progress towards that goal has been slow ${ }^{6}$. Attempts to develop a schistosome vaccine began half a century ago. By analogy with successful microbial and viral vaccines, they involved the vaccination of mice with crude worm extracts or purified components, followed by a cercarial challenge ${ }^{7}$.

Perhaps there were a few key antigens that needed to be identified ${ }^{\boldsymbol{\sigma}}$. So, a particular attention was thus given to identify and characterize sensitive and specific $S$. mansoni antigens to obtain better diagnostic tool and vaccine development ${ }^{8}$.

A few defined soluble antigens were separated to show high sensitivity and specificity in endemic areas ${ }^{9}$. Vaccines in combination with other control strategies, including the use of new drugs, are needed to make elimination of schistosomiasis possible $^{10}$.

Despite the discovery and publication of numerous potentially promising vaccine antigens from $\boldsymbol{S}$. mansoni and, to a lesser extent, Schistosoma hematobium, only one vaccine, namely, BILHVAX, or the 28-kDa GST from Schistosoma hematobium, has entered clinical trials ${ }^{11}$.

By reviewing the most recent and pertinent data on the major vaccine antigens for schistosomiasis; the available antigens and prototype vaccine formulations induce 40 to $50 \%$ protection in animals, at best as shown by reduced worm burden or egg production and viability ${ }^{2}$.
The aim of the present research was the isolation of a cDNA clones from 7-days schistosomula $\lambda$ gt11cDNA library which could be a targets for immune attack and hopefully vaccine candidates for $\boldsymbol{S}$. mansoni elimination.

\section{MATERIALS \& METHODS}

Soluble extract of 7- days schistosomula. Cercariae were kindly offered by the Biochemistry laboratory of Theodore Bilharz Research Institute. Schistosomula were obtained by mechanical transformation of cercariae, then, separated from tails by centrifugation for 15 min over $70 \%$ percoll gradient at $2000 \mathrm{rpm}^{12}$. Schistosomula were recovered, washed three times, and then, incubated in Modified MEM (Minimum Essential Medium containing $10 \%$ foetal calf protein) at $37^{\circ} \mathrm{C}$ in a humidified $5 \% \quad \mathrm{CO}_{2}$ incubator for 7 days. Finally, the living schistosomula were separated by centrifugation for $15 \mathrm{~min}$ at 2000 rpm over $60 \%$ percoll gradient ${ }^{13}$. The soluble extract was made by sonication of the parasites in a buffer containing $20 \mathrm{mM}$ Tris, $\mathrm{pH} 7.2$ and 2 $\mathrm{mM}$ phenyl methyl sulphonyl fluoride (PMSF), then, centrifuged at 6000 rpm for $20 \mathrm{~min}$. The supernatant was collected and stored at $-70^{\circ} \mathrm{C}$.

Affinity purification of sera. Sera used in immunoscreening experiment were pooled from $\boldsymbol{S}$. mansoni chronically infected patients admitted to Department of Tropical Medicine, Zagazig University Hospitals. Cyanogen bromideactivated Sepharose 4B was used to purify sera according to 
manufacturer's instructions by coupling 6-8 $\mathrm{mg}$ of 7-days' schistosomula soluble extract to the column. Pooled sera were precipitated with $45 \%\left(\mathrm{NH}_{4}\right)_{2} \mathrm{SO}_{4}$, the precipitate was redissolved in phosphate buffered saline (PBS) (0.4 g NaCl, 1.44g $\mathrm{Na}_{2} \mathrm{HPO}_{4}$ and $0.24 \mathrm{~g} \quad \mathrm{KH}_{2} \mathrm{PO}_{4} /$ liter) and dialyzed against PBS overnight. The dialysate was, then, passed onto the column coupled to which schistosomular soluble extract. The column was washed with $30 \mathrm{ml}$ PBS. Antibodies bound to the column were eluted by $0.1 \mathrm{M}$ glycine- $\mathrm{HCl}$, $\mathrm{pH} 2.6$ and collected as $1 \mathrm{ml}$ fractions. The $\mathrm{pH}$ of the elute was immediately adjusted to 7.0 with $100 \mu \mathrm{l} 1 \mathrm{M}$ Trisbase., then, it was dialyzed against PBS over night to be ready for immunoscreening.

Immunoscreening

of schistosomula $\lambda$ gt11 cDNA library 14. To grow cells for transfection with the library, a single colony of E.Coli $\boldsymbol{Y} 1090$ was incubated in $50 \mathrm{ml}$ LBampicillin medium (LB-amp) (10 g Bacto-tryptone,5 g Bacto-yeast extract, $10 \mathrm{~g} \mathrm{NaCl}$ and distilled $\mathrm{H}_{2} \mathrm{O}$ up to $1 \mathrm{~L}, \mathrm{pH} 7.0$ ) containing $0.2 \%$ maltose and ampicillin $100 \mathrm{mg} / \mathrm{ml}$ allowed to grow overnight at $37^{\circ} \mathrm{C}$, to be used as hosts for plating the library. For the primary screening of the library, $150 \mathrm{~mm}$ LB-amp plates were used and $90 \mathrm{~mm}$ plates were used for secondary and tertiary screenings. 0.6 $\mathrm{ml} /$ large plate and $0.2 \mathrm{ml} /$ small one of the overnight bacterial culture was incubated with $0.1 \mathrm{ml}$ of SM medium (5.8 g NaCl, $2.0 \mathrm{~g} \mathrm{MgSO}_{4} .7 \mathrm{H}_{2} \mathrm{O}, 50$ $\mathrm{ml} 1 \mathrm{M}$ Tris, $\mathrm{pH} 7.5$ and $5 \mathrm{ml}$ of $2 \%$ gelatin solution/L). The cell suspension was incubated at $37^{\circ} \mathrm{C}$ for 15 min to allow the adsorption of the phage to the bacterial cells. $7 \mathrm{ml} /$ large plate and $3.5 \mathrm{ml} /$ small plate of the molten top agar was cooled to $50^{\circ} \mathrm{C}$ and added to the infected cells, then, poured onto the LB-amp plates pre-warmed to $37^{\circ} \mathrm{C}$. The plates were incubated at $40^{\circ} \mathrm{C}$ for 3-4 hours (hrs). Dry nitrocellulose $(132 \mathrm{~mm}$ and 82 $\mathrm{mm}$ ) circular filters were used for large and small plates, respectively. The filters were saturated in $10 \mathrm{mM}$ IPTG and air dried, then, placed onto the plates. The plates were transferred to a $37^{\circ} \mathrm{C}$ incubator for another $3 \mathrm{hrs}$. then, the filters were removed from the plates and transferred to the Blotto buffer [5g non fat dry milk $/ 100 \mathrm{ml}$ TBST (37.5 ml 4M NaCl, $10 \mathrm{ml} 1 \mathrm{M}$ Tris; $\mathrm{pH}$ 8.0, double distilled $\mathrm{H}_{2} \mathrm{O}$ up to $1 \mathrm{~L}$ and $0.05 \%$ Tween-20 )] to block the non-specific binding protein sites. The filters were, then, washed 3 times in TBST for $10 \mathrm{~min}$ each, followed by incubation for $3 \mathrm{hrs}$ with the purified sera over schistosomula soluble extract column (primary antibody) , then, washed 4 times at room temperature (RT) in TBST for $20 \mathrm{~min}$ each. The anti-rabbit $\mathrm{IgG}$ alkaline phosphatase conjugate (secondary antibody) diluted in TBST was incubated with the primary antibody-antigen complex for $1 \mathrm{hr}$ at RT. Then, the filters were washed 4 times in TBST for $10 \mathrm{~min}$ each, dried and transferred to the colour development substrate solution [33 $\mu$ l of $50 \mathrm{mg} / \mathrm{ml}$ Nitro Blue Tetrazolium $(\mathrm{NBT})+16.5 \mu \mathrm{l}$ of $50 \mathrm{mg} / \mathrm{ml}$ $\mathrm{BCIP} / \mathrm{ml}$ AP buffer $(10 \mathrm{ml}$ of $\mathrm{M}$ Tris; $\mathrm{pH} 9.5,2 \mathrm{ml}$ of $5 \mathrm{M} \mathrm{NaCl} 0.5 \mathrm{ml}$ of 1 $\mathrm{M} \mathrm{MgCl}$, distilled $\mathrm{H}_{2} \mathrm{O}$ up to $100 \mathrm{ml}$ )]. The filters were incubated in dark until the desired colour intensity had been developed, then, rinsed in 
distilled $\mathrm{H}_{2} \mathrm{O}$. The developed filters were used to pick up agar plugs containing phage particles corresponding to the signals on the filters (the positive plaques) to be suspended into $0.5 \mathrm{ml}$ of SM medium. The purified phage plaques were used for the next round of screening.

Polymerase Chain Reaction (PCR) ${ }^{15}$. The isolated phage DNA was amplified using a pair of primers, agt11 forward (5'GGT GGCCACGACTCCTGGAGGCGG$\left.3^{\prime}\right)$ and $\lambda$ gt11 reverse (5-TTGACA CCAGACCAACTGGTAATC-3'). A typical PCR reaction was done $(10 \mu 1$ $10 \mathrm{X}$ Taq DNA polymerase buffer, 16 $\mu \mathrm{l}$ of $1.25 \mathrm{mM}$ dNTP, $5 \mu \mathrm{l}$ forward primer, $5 \mu 1$ reverse primer, $2 \mu 1$ (100 ng) phage DNA template, $0.5 \mu \mathrm{l} \mathrm{Taq}$ DNA polymerase (Perkin-Elmer Cetus and Stratagene), sterile distilled $\mathrm{H}_{2} \mathrm{O}$ up to $\left.100 \mu \mathrm{l}\right)$.The reaction components were mixed in a microfuge and a drop of mineral oil was added. In the thermal cycler (Gene Amp 9600, Perkin-Elmer), a 3file program was used to amplify samples, where they were denatured in the first file at $94^{\circ} \mathrm{C}$ for $1 \mathrm{~min}$, then, the primers were annealed to the denatured templates at $55^{\circ} \mathrm{C}$ for $2 \mathrm{~min}$ and finally extended at $72^{\circ} \mathrm{C}$ for 10 $\mathrm{min}$. The amplicons were withdrawn from underneath the oil and $10 \mu \mathrm{l}$ aliquots were separated on $1 \%$ agarose gel.

Subcloning of the recombinant gene in PCR $^{\mathrm{TM}}$ II plasmid vector ${ }^{16}$. The original TA cloning Kit (Invitrogen) was used for direct insertion of the amplicon into $\mathbf{P C R}^{\mathrm{TM}}$ II vector at EcoRI site. A ligation reaction was prepared (1 $\mu \mathrm{l}$ PCR product , $1 \mu \mathrm{l}$ of $10 \mathrm{X}$ ligation buffer, $2 \mu 1$ plasmid vector, sterile $\mathrm{H}_{2} \mathrm{O}$ up to $9 \mu \mathrm{l}, 1 \mu \mathrm{l}$ DNA ligase), then, incubated overnight at $15^{\circ} \mathrm{C}$ till ready for transformation. The vial containing the ligation reaction was placed on ice. Two $\mu \mathrm{l}$ of $0.5 \mathrm{M} \beta$ mercaptoethanol and $2 \mu \mathrm{l}$ of ligation reaction were added to each vial of the INV competent cells and mixed gently, then, the vial was incubated on ice for $30 \mathrm{~min}$ followed by $30 \mathrm{sec}$ in $42^{\circ} \mathrm{C}$ water bath, then, on ice for 2 min, finally shaked at $37^{\circ} \mathrm{C}$ for $1 \mathrm{hr}$ with $450 \mu \mathrm{l}$ of SOC medium. An aliquot of $50 \mu \mathrm{l}$ was spread onto LBamp plate and the plate was placed inverted at $37^{\circ} \mathrm{C}$ for at least $18 \mathrm{hrs}$. Positive transformants can be selected by using Cracking gel procedure ${ }^{17}$, using $1 \%$ agarose gel electrophoresis.

Small scale preparation of plasmid DNA ${ }^{18}$. A single bacterial colony that contains the desired plasmid was used to inoculate $100 \mathrm{ml}$ of LB-amp medium incubated at $37^{\circ} \mathrm{C}$ with vigorous overnight shaking $(\mathrm{O} / \mathrm{N})$. The bacterial cells were centrifuged at $10000 \mathrm{rpm}$ for $10 \mathrm{~min}$. For cells lysis solution I was used (50 $\mathrm{mM}$ glucose, $25 \mathrm{mM}$ Tris $\mathrm{HCl}, \mathrm{pH} 8$, $10 \mathrm{mM}$ EDTA, pH 8) and freshly prepared lysozyme was added, then, followed by solution II $[0.2 \mathrm{M}$ $\mathrm{NaOH}, 1 \%$ sodium dodecyl sulphate (SDS)], the suspension was incubated at room temperature (RT) for $10 \mathrm{~min}$ followed by adding $20 \mathrm{ml}$ of solution III (3 M potassium acetate, $2 \mathrm{M}$ glacial acetic acid). DNA was recovered by adding an equal volume of isopropanol and precipitated by centrifugation at $10000 \mathrm{rpm}$ for 10 min at RT. The pelleted DNA was dissolved in $100 \mu \mathrm{l}$ distilled $\mathrm{H}_{2} \mathrm{O}$ to which RNase $(10 \mathrm{mg} / \mathrm{ml})$ was added, 
then, left for incubation at $37^{\circ} \mathrm{C}$ for 2 hrs. The DNA solution was, extracted with phenol-chiasm, then, precipitated by ethanol 2.5 volumes and 0.1 volume of $3 \mathrm{M}$ sodium acetate. DNA pellet was dissolved in $50 \mu \mathrm{l}$ distilled $\mathrm{H}_{2} \mathrm{O}$. O.D $\mathbf{D}_{260}$ was used to quantitate the DNA then, stored at $-20^{\circ} \mathrm{C}$.

DNA sequencing using fmol DNA System (Promega) ${ }^{19}$. In each one of four microfuges labeled $(\mathrm{G}, \mathrm{A}$, $\mathrm{T}, \mathrm{C}), 2 \mu \mathrm{l}$ of $\mathrm{d} / \mathrm{ddNTPs}, 1 \mu \mathrm{g}$ DNA template, $25 \mu \mathrm{g}$ primer (M13 at $5^{\prime}$-end and $\mathrm{T} 7$ a 3 -end) $1 \mu \mathrm{l}$ of $\alpha-{ }^{35} \mathbf{S}, 5 \mu \mathrm{l}$ sequencing buffer and deionized distilled (dd) $\mathrm{H}_{2} \mathrm{O}$ up to $16 \mu$ were mixed, then, to each tube $1 \mu \mathrm{l}$ of sequencing grade Taq DNA polymerase was added to the template/primer mix. The tubes were placed in a thermal cycler to follow this profile, $2 \mathrm{~min}$ at $95^{\circ} \mathrm{C}, 30 \mathrm{sec}$ at $90^{\circ} \mathrm{C}$, then, $1 \mathrm{~min}$ at $70^{\circ} \mathrm{C}$ for 30 cycle. The reaction was stopped by adding $3 \mu \mathrm{l}$ stop solution to each tube. $3 \mu \mathrm{l}$ of each tube were loaded onto the sequencing gel ( $8 \%$ Polyacrylamide, 8 $\mathrm{M}$ urea gel), the run was continued for 2.5 and 6.5 hrs.. After the electrophoresis, the gel was fixed in a solution of $10 \%$ acetic acid and $10 \%$ methanol for $30 \mathrm{~min}$, dried by heating, then, exposed to an X-ray film, which was developed and the information obtained from DNA sequence was analyzed using the Genetics Computer Group Sequence analysis Software package.

\section{RESULTS}

Sera obtained from S. mansoni chronically infected patients were purified over an antigen coupled column made from soluble extract of 7-days schistosomula. The elute containing affinity purified antibodies was used to immunoscreen 7-days schistosomula $\lambda$ gt11 cDNA library. One of the identified cDNA clones by affinity purified antibodies (clone 465) contained a $0.9 \mathrm{~kb}$ insert. The full DNA sequence of the clone showed a single open reading frame (ORF) of 269 amino acids with high identity (94\%) to the gene of SJCHGC 03921 protein of Schistosoma japonicum.

The 0.9 clone which was completely sequenced in both directions after being inserted into $\mathbf{P C R}^{\mathrm{TM}}$ II vector, did not contain the entire coding region. The $5^{\prime}$ - upstream region in the sequence obtained showing that the first initiation codon (ATG) is located $-201 \mathrm{bp}$ from the beginning of this region with neither transcription activation TATA nor CAAT boxes. There are three putative polyadenylation signals AAATAA, AATTA and ATAA located +114 , +22 and $+6 \mathrm{bp}$, respectively, from the 3 -downstream region, there is no polyadenylation site (poly A tail) (Fig. 1).Some of the isolated clones were checked for their sizes after being inserted in the plasmid vector using two restriction enzymes EcoRI and BamH1 (Fig. 2), all clones showed no BamH1 site, while, being digested by EcoR1 gave the actual size of each insert. The selected clone was sequenced using two primers (M13 from the $5^{/-}$end and T7 from the $3^{\prime}$ end) followed by another two pairs of primers to complete the sequence of the isolated clone, each sequence gel was exposed to an X- ray film for 24 hrs, then, developed and read from the bottom of the autoradiogram (Fig. 3). 


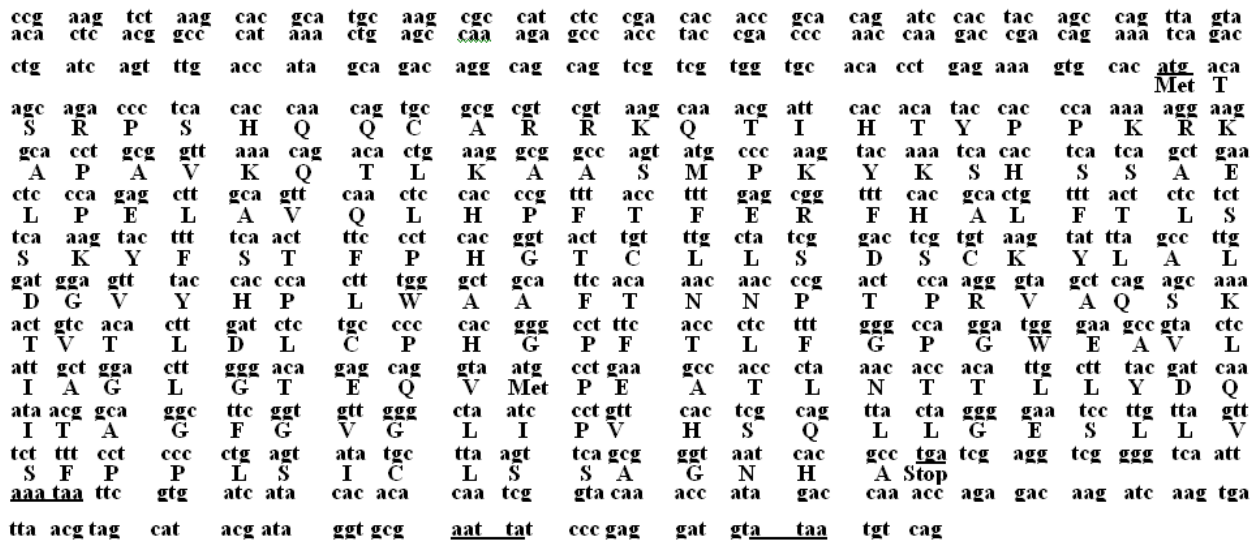

Fig. 1: The Complete nucleotide and deduced amino acids sequences of the gene encoding $\boldsymbol{S J C H G C ~} 03921$ protein of $\boldsymbol{S}$. mansoni isolated from $\boldsymbol{\lambda}$ gt11cDNA library of 7-days schistosomula, start codon (ATG), stop codon (TGA), three polyadenylation signals (AAATAA), (AATTA) and (ATAA) are underlined.

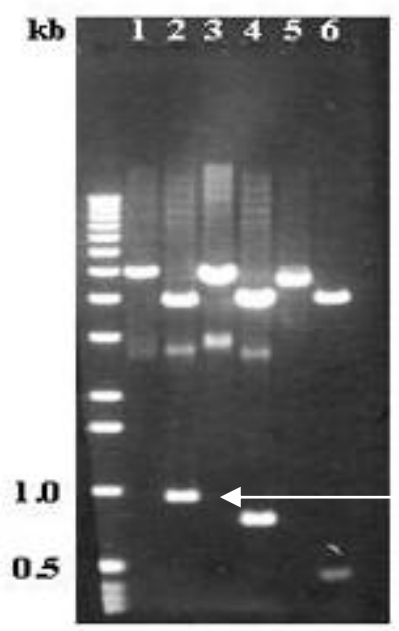

Fig. 2: $1 \%$ agarose gel showing the digestion pattern of three isolated clones from $\lambda$ gt11 cDNA library of 7-day schistosomula, cloned in $\mathbf{P C R}{ }^{\mathrm{TM}} \mathbf{I I}$ vector, digested by two restriction enzymes EcoR1 and BamH1, the plasmid DNA samples were arranged in double, each represents from left to right, EcoR1 digested and BamH1 digested DNA. $1 \mathrm{~kb}$ ladder was indicated on the left side of the gel. The selected clone (4-65) was run in lanes 1 and 2, its size is $0.9 \mathrm{~kb}$. 


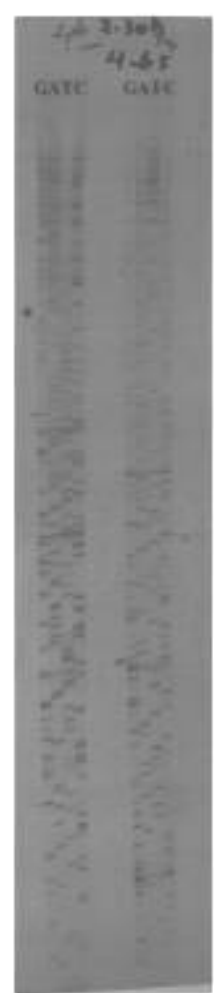

Fig 3: An autoradiogram showing sequence of the gene encoding SJCHGC 03921 protein of $\boldsymbol{S}$. mansoni isolated from $\lambda$ gt11 cDNA library of 7-days schistosomula cloned in $\mathbf{P C R}{ }^{\mathrm{TM}} \mathbf{I I}$ vector.

\section{DISCUSSION}

A world wide problem is that over 200 million people have and another 600 million are at risk of contracting schistosomiasis ${ }^{20}$.

The recent studies on schistosomiasis have focused on identification and characterization of defined antigens that may have vaccine and/ or diagnostic potential.
The development of vaccine against schistosomiasis would provide a powerful tool for the control of this important parasitic disease and it must be effective which should be confirmed by protection test ${ }^{21}$.

Several vaccine strategies have been tried such as the use of synthetic peptides ${ }^{22}$.

The tegument associated antigens expressed on newly transformed and developing schistosomules and involved in important host-parasite interactions are important candidates for vaccine development ${ }^{23}$.

The current research was focusing on identification, characterization and study of the vaccine potential of tegumental and internal antigens of 7days schistosomula. The technique used was not the extraction of surface proteins only, but all the parasite was sonicated for obtaining all antigens either they are tegumental or internal. After three rounds of immunoscreening of $\lambda$ gt11 cDNA library of 7-days schistosomula by affinity purified antibodies obtained from the sera of patients, a number of cDNA clones were isolated, one of them (clone 4-65) was amplified by PCR using $\lambda$ gt11 forward and reverse primers, then, cloned in $\mathbf{P C R}^{\mathrm{TM}} \mathbf{I I}$ vector. The size of the selected clone was shown to be $0.9 \mathrm{~kb}$ by checking the pattern of restriction endonuclease digestion using EcoR1 and BamH1 enzymes, the result of enzymatic digestion was run on $1 \%$ agarose gel, the digestion by EcoRI proved the size of the insert. The DNA sequence did not contain the entire coding region of the gene. The upstream region the transcription activation 
boxes (TATA and CAAT) were not found, similarly, there is no polyadenylation site in the downstream region. The DNA sequence of the identified clone showed that it has (94\%) homology with the gene that encodes SJCHGC 03921 protein of Schistosoma hematobium.

${ }^{24}$ reported some of the most promising $\boldsymbol{S}$. mansoni vaccine antigens as well as those that were independently tested under the umbrella of the TDR/WHO committee in the mid-1990s, the group of isolated antigens includes tetraspanins, although their functions are unknown, but a family of them is expressed in the schistosome tegument and at least three of these show promise as vaccines.

$\mathrm{Sm} 23$ is a tetraspanin expressed in the tegument of S. mansoni and is one of the independently tested WHO/TDR vaccine candidates, it is the most efficacious when delivered as a DNA vaccine ${ }^{25}$ and does not confer protection as a recombinant protein when formulated with alum.

Sm28-GST has GST properties and is expressed in subtegumental tissues of most developmental stages of the parasite. Vaccination of semipermissive rats and permissive hamsters with recombinant Sm28GST resulted in significant reductions of worms ${ }^{26}$.

Also, the group of the selected antigens includes Smp80 calpain ${ }^{27}$ which is a calcium-activated neutral cysteine protease, superoxide dismutase (SOD) which inhibits granulocyte toxicity for egg metabolic activity and hatching 28 and paramyosin which is expressed on the surface tegument of lung-stage schistosomula in the penetration glands of cercariae ${ }^{29}$.

FABP (Sm 14), the $\boldsymbol{S}$. mansoni fatty acid binding protein, despite a high efficacy of recombinant Sm14 protein in mouse vaccine trials ${ }^{30}$, Sm14 failed to induce protection levels of $>40 \%$ when tested in different laboratories ${ }^{31}$.

The current Schistosoma vaccine candidates may prove not to be the most effective. It is important to identify new target antigens and to explore alternative vaccination strategies to improve vaccine efficacy 32 .

There is an abundance of reports on schistosome antigens obtained from different anatomic locations and stages of the developing parasite. The tegument antigens of a live worm are those that researchers focus efforts are truly exposed to the host immune system, so, the tegument plasma membrane proteins should be a major focus for future vaccinology efforts ${ }^{33}$, because a focus on identification of new intracellular antigens show moderate protection at best ${ }^{34}$.

The deficits in lipid metabolism that makes schistosomes dependent on the host are revealed and the identification of membrane receptors, ion channels and more than 300 proteases provide new insights into the biology of the life cycle and novel targets 35 .

There is shortage of informations about the isolated gene in this study which advocate continuing the efforts to perform further researches for picking up the full length gene, identifying its localization, its function and its vaccine potential. 


\section{ACKNOWLEDGEMENT}

Thanks for every member in the biochemistry laboratory in Theodore Bilharz Research Institute especially Prof. Mohamad Ali Saber for providing all materials used in the research and their technical assistance.

\section{REFERENCES}

1. Clements, A.C., Bosque-Oliva, E., Sacko, M., Landoure, A., Dembele, R., Traore, M., Coulibaly, M., Gabrielli, A.F., Fenwick, A., Brooker, S. (2009): A comparative study of the spatial distribution of schistosomiasis in Mali in 19841989 and 2004-2006. Plos Negl Trop. Dis., 3: e431

2. Donald P. M. and Alex L. (2008): Current Status of Vaccines for Schistosomiasis. Clinical Microbiology Reviews, p. 225-242, Vol. 21, No. 1

3. Smithers, S.R. and Terry, R.J. (1969): Immunity in schistosomiasis. Ann. N.Y. Acad. Sci., 160:826-840.

4. Soisson, L.M.A., Masterson, C.P., Tom, T.D., McNally, M.T., Lowel, G.H.and Strand, M. (1992): Induction of protective immunity in mice using a $62-\mathrm{kDa}$ recombinant fragment of Schistosama mansoni surface antigen. J. Immunol., 149:3612-3620.

5. Gary, P. Dillon, Theresa, Feltwell, Jason, Skelton, Patricia, S. Coulson, R. Alan, Wilson, and Alasdair, C. Ivens (2008): Altered patterns of gene expression underlying the enhanced immunogenicity of radiation-attenuated

schistosomes. PLoS Negl

Trop.Dis., 21: 2(5): e240.

6. Alan, R. Wilson and Patricia, S. Coulson (2006): Schistosome vaccines: a critical appraisal. Mem. Inst. Oswaldo Cruz., 101 Suppl 1:13-20.

7. Hayunga, E.G. (1985): Attempted immunization of mice against $S$. mansoni by inoculation with purified glycoprotein antigens from adult worms. Proc. Helminth Soc., 52: 184-195.

8. Alarcon, de Noya , B., O. Noya, R. Ruiz, C. Colmenares, S. Losada, R.Contreras, A. Bruces, G. Certad, A. Hernan, C. Sierra, J. Toro, N Chacon and L.M. Cesari (2003): Prevalencia de la parasitosis intestinales y esquistosomosis en comuidades del area centro notre de Venezuela. Bol.Malariol.San. amb., XLIII: 21-30.

9. Valli, L.C.P., Kanamura, R.M., DaSilva, R.Rebiero-Rodrigues and R. Dietze (1999): Schistosomiasis mansoni: Immunoblot to diagnose and differentiate recent and chronic infection. Am. J.Trop.Med.Hyg., 61:303-307.

10. Todd, C. W. and D. G. Colley (2002): Practical and ethical issues in the development of a vaccine against schistosomiasis mansoni. Am. J. Trop. Med. Hyg., 66:348-358

11. Capron, A., G. Riveau, M. Capron, and F. Trottein (2005): Schistosomes: the road from hostparasite interactions to vaccines in clinical trials. Trends Parasitol., 21:143-149 
12. Lazdins, J.K., Stein, M., David, J.B. and Sher, A. (1982): Schistosoma mansoni: rapid isolation and purification of schistosomula of different developmental stages by centrifugation on a discontinuous density gradient of percoll. Exp. Parasitol., 53: 39-44.

13. Basch, P.F. (1981): Cultivation of Schistosama mansoni in vitro. I. Establishment of cultures from cercariae and development until pairing. J. Parasitol., 67:179-185.

14. Huynh, T.V., Young RA. and Davis, R.W. (1985): Construction and screening cDNA libraries in lambda gt 10 and lambda gt 11 in DNA Cloning: A practical Approach (Glover, D. M. ed.), vol. 1, pp. 49 - 78. IRL Press. Washington, D.C.

15. Saiki, R. K., Gelford, D. H., Stoffel, S., Scharf, S. J., Higushi, R., Harn, G. T., Mullis, K. B. and Erlich, H. A. (1988) : Primer -directed enzymatic amplification of DNA with thermostable DNA polymerase. Science 239: 487-91.

16. Maniatis, T., Fritsch, E. F. and Sambrook, J. (1982): Molecular Cloning .A laboratory Manual. Cold Spring Harbor Laboratory., Cold Spring Harbor. New York.

17. Hanahan, D. (1983): Studies on Transformation of Escherichia Coli with plasmids. J. Mol. Biol. , 166: 557- 80

18. Sambrook, J., Fritsch, E.F. and Maniatis, T. (1989): "Molecular Cloning: A laboratory Manual, "2nd. ed. Cold Spring Harbor. Laboratory Press New York.
19. Moran, L.S., Maina, C.V., Poole, C. B., Slatko, B. E. (1990): Nucleotide sequence of phage $\lambda$ gt 11 Sac $1-$ Kpni, lac Z region. Gene 93 (1):163-64.

20. Tori, C.F., Euihye, J. and Edward, J. P. (2007): Parasite flatworm Schistosoma mansoni. Plos Pathog., 3 (4): c52.

21. Thomas, M., Kariuke, G, J., Van, D., Andre, M., Deedler, I., Farah, O., Doreas, S., Yole, R., Alan, W. and Patricia S. C. (2006): Previous or ongiong schistosome infections do not compromise the efficacy of the attenuated cercaria vaccine. Infect. Immun., 74 (7): 3979 3986.

22. Miller, S., Rekosh, D.M. and LoVerde, P.T. (1989): Schistosoma mansoni: identification and characterization of Schistosoma polypeptides Exp. Parasitol., 69:249-262.

23. Fonseca, T.C Chunha-Neto, E. Kalil, J., De Jesus, R.A., Correa - Oliveria R., Caravalho, M. M. and Oliveira, C.S. (2004b): Identification of immunodominant epitopes of schistosome mansoni vaccine candidate antigens using human T-cells. Mem. Inst. Oswaldo. Cruz, Vol. 99. Suppl., 1: 63-68.

24. Bergquist, N. R., and D. G. Colley (1998): Schistosomiasis vaccines: research and development. Parasitol., Today 14:99-104.

25. Da'Dara, A. A., P. J. Skelly, C. M. Walker, and D. A. Harn (2003): A DNA-prime/proteinboost vaccination regimen enhances Th2 immune responses 
but not protection following Schistosoma mansoni infection. Parasite Immunol., 25:429-437.

26. Balloul, J. M., J. M. Grzych, R. J. Pierce, and A. Capron (1987): A purified 28,000 dalton protein from Schistosoma mansoni adult worms protects rats and mice against experimental schistosomiasis. J. Immunol., 138:3448-3453.

27. Andresen, K., T.D. Tom, and M. Strand (1991): Characterization of cDNA clones encoding a novel calciumactivated neutral proteinase from Schistosoma mansoni. J. Biol. Chem., 266:15085-15090

28. Kazura, J. W., P. de Brito, J. Rabbege, and M. Aikawa (1985): Role of granulocyte oxygen products in damage of Schistosoma mansoni eggs in vitro. J. Clin. Investig., 75:12971307.

29. Gobert, G. N., and D. P. McManus (2005): Update on paramyosin in parasitic worms. Parasitol. Int., 54:101-107.

30. Tendler, M., C. A. Brito, M. M. Vilar, N. Serra-Freire, C. M. Diogo, M. S. Almeida, A. C. Delbem, J. F. Da Silva, W. Savino, R. C. Garratt, N. Katz, and A. S. Simpson (1996): A Schistosoma mansoni fatty acidbinding protein, Sm14, is the potential basis of a dual-purpose anti-helminth vaccine. Proc. Natl. Acad. Sci., USA 93:269-273

31. Fonseca, C. T., C. F. Brito, J. B. Alves, and S. C. Oliveira. (2004a): IL-12 enhances protective immunity in mice engendered by immunization with recombinant 14 kDa Schistosoma mansoni fatty acid-binding protein through an IFN-gamma and TNF-alpha dependent pathway. Vaccine 22:503-510.

32. Bergquist, N. R., L. R. Leonardo, and G. F. Mitchell (2005): Vaccine-linked chemotherapy: can schistosomiasis control benefit from an integrated approach? Trends Parasitol., 21:112-117.

33. Loukas, A., M. Tran, and M. S. Pearson (2007): Schistosome membrane proteins as vaccines. Int. J. Parasitol., 37:257-263

34. Braschi, S., R. S. Curwen, P. D. Ashton, S. Verjovski-Almeida, S. and A. Wilson (2006): The tegument surface membranes of the human blood parasite Schistosoma mansoni: a proteomic analysis after differential extraction. Proteomics 6:1471-1482.

35. Berriman, M., Brian, J. H., Philip, T. L., Alan, W. R., Gary, P. D., Gustavo, C. C., Susan, T. M., Al-Lazikani, B., Luiza, F. A., Peter, D. A., Martin, A. A., Daniella, C. B., Gaelle, B., Conor, R. C., Avril, C., Richard, C., Tim, A. D., Art, D., Ricardo, D., Appoliniare, D., Tina, E., John, A. G., Elodie, G., Yong, G., Christiane, H., Hirohisha, H., Yuriko, H., Robin, H., Alasdair, I., David, A. J., Daniela, L., Camila, D. M., Paul, M., Zemin, N., Guilherme, O., John, P. O., Julian, P., Mihaela, P., Raymond, J. P., Anna. V. P., Michael, A. Q., Marie-Adèle, R., Jane, R., Mohammed, S., 
Steven, L. S., Mario, S., Adrian, R. T., Owen, W., David, L. W., Jennifer, W., Wenjie, W., Mostafa, Z., Adhemar, Z., Claire, M. F., Barclay, G. B., and Najib M. E.(2010): The genome of the blood fluke Schistosoma mansoni. Nature. 16; 460(7253): 352-358.

\section{التوصيف الجزيئي للجين المنتج لبروتين من الطور الصدري لطفيل الشستوسوما مانسوناى لئن}

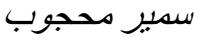

قسم الكيمياء الحيويةـ كلية الطبـ- جامعة المنيا

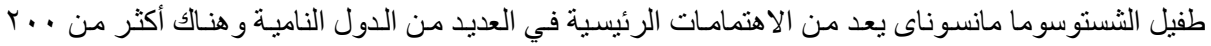

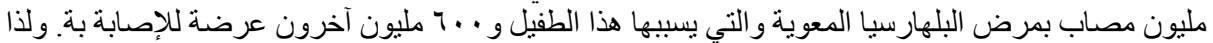

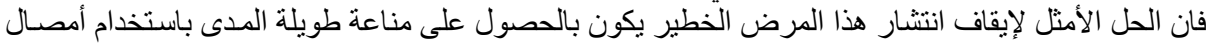

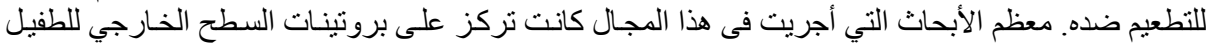

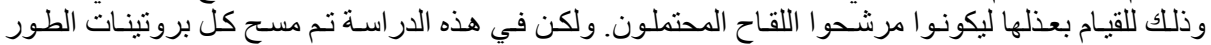

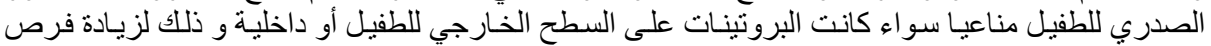

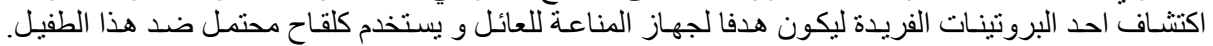

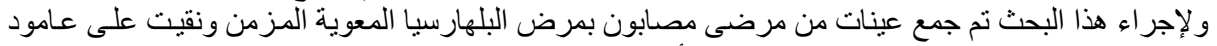

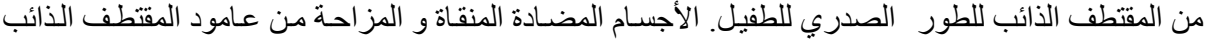

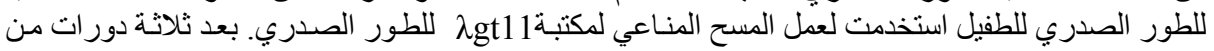

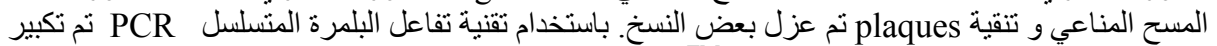

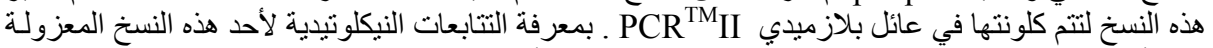

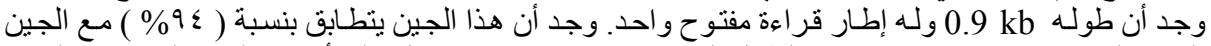

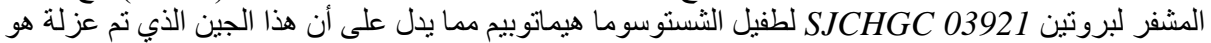

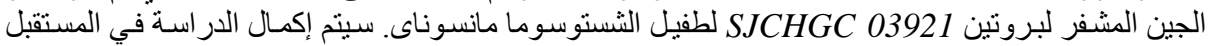

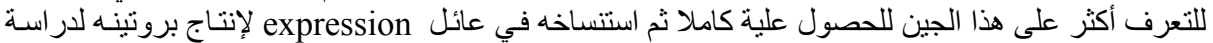
ما إذا كان من المككن استخدامه كأحد اللقاحات المرشحة للاستخدام ضد طفيل عليل الثستوسوما مانسوناى.
} 